\title{
Analisis Faktor-Faktor yang Mempengaruhi FDR Bank Umum Syariah (Studi Kasus PT Bank Muamalat Indonesia Tbk)
}

\author{
Analysis of factors affecting FDR of sharia commercial bank (Case study of PT Bank \\ Muamalat Indonesia Tbk
}

\section{Hanafi Nugraha}

Program Studi D4 Keuangan Syariah, Politeknik Negeri Bandung

E-mail: hanafi.nugraha.ksy16@polban.ac.id

\section{Destian Arshad \\ Jurusan Akuntansi, Politeknik Negeri Bandung \\ E-mail: destian.arshad@polban.ac.id}

\begin{abstract}
The purpose of this study is to analyze factors that affect the liquidity capability of Islamic banks in Indonesia. One of the ratios which used to measure the ability of liquidity and to assess the financial performance of an Islamic bank is FDR. variables which used are ROA, CAR, NIM, and BI Rate. The data used in the study were secondary data on the quarterly financial statements of PT. Bank Muamalat Indonesia Tbk for the period 2012-2019. The research model or analysis tool used in this study is multiple linear regression analysis using statistical data processing applications. The results of this research are that the variables $\mathrm{ROA}, C A \mathrm{R}, \mathrm{NIM}$, and BI Rate have a simultaneous effect on FDR and partially NIM and BI Rate bave a significant effect on FDR, while $\mathrm{RO} A$ and $C A R$ partially do not have a significant effect on FDR.
\end{abstract}

Keywords: FDR, ROA, CAR, NIM and BI Rate

\section{Pendahuluan}

Bank syariah adalah lembaga keuangann bank yangg dijalankan berdasarkan prinsip syariah dimana pada sistem operasinya tidak mengandalkan pada bunga melainkan mengandalkan bagi hasil dan memiliki fungsi utama sebagai lembaga iintermediasi atau Lembaga kepercayaan antara masyarakat yang kelebihan dana dengan masyarakat yang kekurangan dana. Dengan aturan pelaksana PP No. 72/1992 tentang Bank berdasarkan Prinsip Bagi Hasil, maka mulai beroperasilah Bank Muamalat Indonesia pada tahun 1992. Kehadiran bank syariah di Indonesia diperkuat setelah disahkannya UU No. 10 tahun 1998 pasal 8 ayat 2 yang menegaskan bahwa sistem perbankann syariah ditempatkan sebagai bahan sistem perbankan nasional. Pembiayaan yang disalurkan kepada masyarakat mempunyai manfaat baik bagi masyarakatt maupun bagi bank syariah. Manfaat bagi masyarakat yaitu mendapatkan dana, yang perolehan dana tersebut dapat digunakan untuk pembiayaan produktif atau pembiayaan konsumtif, sedangkan bagi bank syariah akan memperoleh pendapatan bagi hasil dan dari pembiayaan tersebut akan menggerakkan roda perekonomian. Memenuhi permintaan pembiayaan yang diajukan dan sudah disetujui dapat menunjukan kemampuan bank syariah tersebut dalam memenuhi kecukupan likuiditas banknya

Menurut (Fahmi, 2015), secara umum, likuiditas adalah kemampuann suatu perusahaan memenuhii kewajiiban jangkapendeknya secara tepat waktu. Rasio Likuiditas yang penulis pilih dalam menilai likuiditas bank dalam memenuhi pembiayaan atau kewajiban jangka pendeknya suatu 


\section{Hanafi Nugraha, Destian Arshad}

bank syariah adalah FDR (Financing to Deposit Ratio). Financing to Deposit Ratio (FDR) diperoleh dari jumlah pembiayaan yang disalurkan kepada masyarakat dibagi dengan total simpanan yang diterima dari masyarakat. Dimana jumlah pembiayaan yang disalurkan terdiri dari pembiayaan berdasarkan prinsip bagi hasil, jual beli, sewa dan prinsip lainnya. Total simpanan yang diterima dari masyarakat yang biasa disebut juga Dana pihak ketiga (DPK) yang berasal dari rekening giro, rekening tabungan, dan rekening deposito. Sehingga, semakin besar tingkat FDR berarti semakin banyak dana yang disalurkan kembali ke masyarakat dalam bentuk pembiayaan dari dana yang terkumpul di bank (Setiawan, 2018).

Hingga tahun 2019 ini, OJK dan IB belum mengatur batasan FDR bagi perbankan syariah. Meskipun belum diatur, batasan FDR pada perbankan konvensional yang disebut dengan loan to deposit ratio (LDR) yang sekarang menjadi loan to funding ratio (LFR) menurut menurut (Bank Indonesia, 2015) dalam PBI No. 17/11/PBI/2015 ditetapkan sebesar 78\%-92\%. Karena secara pemahaman hampir sama dengan konsep LDR dimana keduanya sama-sama berfungsi mengukur tingkat likuiditas perbankan dan juga melihat rasio dari total pembiayaan dengan DPK, hanya saja FDR tidak menganut sistem bunga dalam menyalurkan dana.

Belum diaturnya FDR pada perbankan syariah mengakibatkan adanya beberapa bank syariah yang nilai FDR nya dibawah batasan tingkat LDR yang diatur Bank Indonesia untuk Bank Konvensional. Salah satu bank syariah tersebut adalah Bank Muamalat Indonesia. Dibawah ini adalah gambar yang mengambarkan Financing to Deposit Ratio (FDR) PT Bank Muamalat Indonesia Tbk.

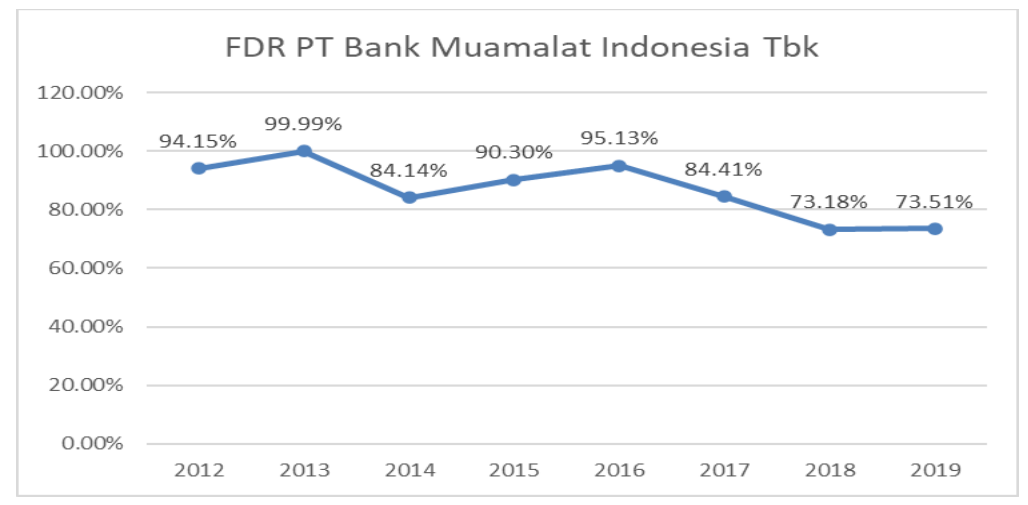

Gambar 1. Grafik FDR PT Bank Muamalat Indonesia Tbk Tahun 2012-2019

Pada grafik diatas terlihat bahwa dari tahun 2016, FDR Bank Muamalat Indonesia terus menurun dan juga apabila berpacu pada peraturan BI yang mengatur LDR, maka Bank Muamalat Indonesia diharuskan membayar sanksi sesuai dengan ketentuan Bank Indonesia karena pada tahun 2018 dan tahun 2019, FDR BMI sebesar 73,18\% dan 73,51\%. Hal ini mengambarkan bahwa dana yang disalurkan sebagai pembiayaan kepada masyarakat yang dibandingkan dengan dana yang tersedia kurang optimal karena lebih tinggi penurunan. Hal ini tentu menjadi fenomena yang menarik diteliti, karena Bank Muamalat Indonesia sebagai salah satu Bank Umum Syariah (BUS) pertama di Indonesia dan sedang memliki masalah dalam permodalan sehingga membutuhkan dana dari investor dengan berusaha menjual saham atau right issue.

Penulis pun membandingkan variabel faktor internal dan faktor eksternal yang diduga mempunyai hubungan dengan FDR yang penulis pilih yaitu CAR, ROA, NIM dan BI Rate PT Bank Muamalat Indonesia Tbk untuk mengetahui apakah sudah sesuai dengan teori atau ada yang tidak sesuai. Berikut dibawah ini adalah gambar grafik yang mengambarkan perbandingan ROA, CAR, NIM, BI Rate dan FDR PT Bank Muamalat Indonesia Tbk pada 2012 hingga 2019. 


\section{Hanafi Nugraha, Destian Arshad}

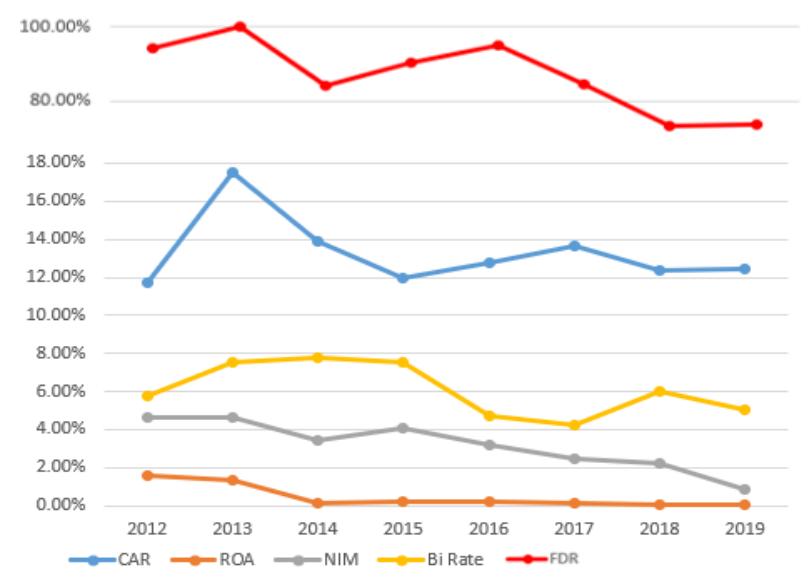

Gambar 2. Grafik Perbandingan Variabel yang diduga mempengaruhi FDR

Berdasarkan grafik di atas bahwa kenaikan dan penurunan pada tingkat Capital Adequacy Ratio (CAR) tidak sesuai dengan teori yang menyatakan bahwa apabila modal yang tersedia untuk mengatasi risiko bertambah, maka diduga pembiayaan yang disalurkan akan meningkat, sehingga kenaikan nilai CAR diperkirakaan berbanding lurus dengan kenaikan tingkat Financing to Deposit Ratio (FDR). Hal ini terlihat pada tahun tahun 2014-2015 dimana modal yang tersedia untuk mengantisipasi risiko pembiayaan berkurang atau nilai CAR pada grafik terlihat menurun, tetapi pada grafik yang sama nilai FDR nya naik. Dan juga pada tahun 2016-2017, nilai CAR naik, tetapi nilai FDR nya terlihat menurun.

Begitu juga dengan Net Income Margin (NIM), rasio pendapatan bersih bagi hasil terhadap total rata-rata aktiva produktif yang dimana sebagian pendapatan bersih bagi hasil itu disalurkan kepada modal dan akan meningkatkan tingkat CAR. Pada Net Income Margin (NIM) atau Net Imbalan (NI) juga terjadi ketidaksesuiaan dengan teori yang menyatakan bahwa apabila semakin lebih baik bank syariah menghasilkan pendapatan bersih bagi hasil maka semakin banyak dana simpanan masyarakat yang akan disalurkan dalam pembiayaan sehingga menjadi aktiva produktif. Oleh sebab itu, diduga NIM berbanding lurus dengan FDR. Ketidaksesuaian dengan teori terjadi pada periode 2015-2016, dimana kemampuan manajemen Bank dalam pengelolaan aktiva produktif untuk menghasilkan laba bersih atau nilai NIM pada grafik terlihat menurun tetapi pada periode yang sama nilai FDR terlhat naik.

Selain NIM, ada rasio rentabilitas yang mengukur kemampuan perusahaan dalam mendapatkan laba dari mengeloa aset yang dimiliki yaitu ROA. Pada tahun 2012-2013 pun terdapat ketidaksesuaian dengan teori yang menyatakan bahwa semakin bagus bank dalam mengelola asset yang dimiliki, yang sebagian besar dana simpanan masyarakat. Dimana dalam pengelolaaannya, dana tersebut harus disalurkan dalam bentuk pembiayaan dan akan menghasilkan laba dari aset tersebut, berarti akan semakin banyak pembiayaan yang akan disalurkan. Sehingga ROA diperkirakan berbanding lurus dengan FDR. Tetapi pada tahun 2012-2013, kemampuan perusahaan dalam mendapatkan laba dari mengelola asset atau nilai ROA terlihat menurun, tapi pada tahun yang sama terlihat nilai FDR naik.

Berdasarkan grafik di atas bahwa kenaikan dan penurunan pada tingkat BI Rate terdapat ketidaksesuaian dengan teori yang diperkirakan bahwa apabila BI Rate naik, maka suku bunga kredit bank konvensional akan naik, begitu juga dengan marjin bank syariah yang ikut meningkat karena salah satu referensi marjin keuntungan ditetapkan berdasarkan tingkat suku bunga rata-rata perbankan konvensional. Sehingga apabila marjin bank syariah meningkat maka pembiayaan yang 


\section{Hanafi Nugraha, Destian Arshad}

disalurkan akan berkurang, dan tingkat FDR pun akan menurun. Ketidaksesuaian terjadi pada tahun 2012-2013 dimana BI Rate terlihat naik, tetapi pada periode yang sama nilai FDR terluhat mengalami kenaikan dari periode sebelumnya. Dan juga pada tahun 2016-2017, BI Rate terlihat turun, sedangkan FDR pada periode yang sama terlihat menurun juga.

Selain ketidaksesuaian antara teori dan fakta di Bank Syariah Bank Muamalat Indonesia Tbk, pada periode 2012-2019 yang menunjukkan terjadinya penyimpangan antara teori dengan praktik. Terdapat ketidakonsitstenan antara penelitian satu dengan penelitian lainnya. Dari beberapa penelitian yang dilakukan mengenai faktor-faktor yang mempengaruhi FDR pada bank syariah diperoleh hasil yang berbeda-beda. Seperti menurut (Astuti, 2016), Variabel ROA memiliki pengaruh negatif terhadap FDR. Sedangkan menurut (Ramadhani \& Indriani, 2016), ROA berpengaruh positif tidak signifikan terhadap LDR, CAR berpengaruh negatif tidak signifikan terhadap FDR dan Menurut (Sulistiana, 2018), CAR berpengaruh positif namun tidak signifikan terhadap FDR.

Penelitian ini bertujuan untuk menganalisis Faktor-Faktor Yang Mempengaruhi Financing to Deposit Ratio (FDR) Bank Umum Syariah (Studi Kasus PT Bank Muamalat Indonesia Tbk Periode 2012-2019)

\section{Kajian Pustaka}

\subsection{Financing To Deposit Ratio (FDR)}

FDR menurut Ginting dkk dalam (Fathonah \& Hermawan, 2020) merupakan rasio yang menunjukkkan kesehatan bank syariah dalam memberikan pembiayaan kepada masyarakat dalam kegiatan operasional bank, rasio pembiayaan yang diberikan kepada pihak ketiga dalam rupiah dan valuta asing, tidak termasuk pembiayaan pada bank lain, terhadap dana pihak ketiga yang mencakup giiro, tabungan, deposito, dalam rupiah dan valuta asiing, tidak termasuk antar bank.

\subsection{Return On Assets (ROA)}

Return on Asset menurut Setiawan dan Sari dalam (Fathonah \& Hermawan, 2020) merupakan rasio yang menggambarkan kemampuan bank dalam mengelola dana yang diinvestasikan dalam keseluruhan aktiva yang menghasilkan keuntungan. ROA menurut Muhammad dalam (Fathonah \& Hermawan, 2020) adalah gambaran produktivitas bank dalam mengelola dana sehingga menghasilkan keuntungan.

\subsection{Capital Adequacy Ratio (CAR))}

Capital Adequacy Ratio (CAR) adalah rasio solvabilitas untuk mengukur kecukupan modal yang dimiliki oleh suatu bank untuk menunjang aktiva yang menghasilkan risiko, misalnya kredit yang telah diberikan kepada nasabah. (Fahmi, 2015). Menurut (Sa'idah \& Mauluddi, 2018) salah satu faktor penting dalam rangka pengembangan usaha bisnis dan menampung resiko kerugian adalah modal, kemampuan Bank dalam menanggung resiko dari setiap aktiva produktif yang beresiko dapat diukur dengan nilai CAR dan tinggi rendahnya nilai CAR berbanding lurus dengan kuat tidaknya sebuah Bank dalam menanggung resiko yang diakibatkan dari setiap aktiva produktif yang berisiko, dan salah satu aktiva produktif adalah pembiayaan.

\subsection{Net Income Margin (NIM)}

NIM menurut (Otoritas Jasa Keuangan, 2014) dalam SEOJK Nomor 10/SEOJK.03/2014 tentang Penilaian Tingkat Kesehatan Bank Umum Syariah dan Unit Usaha Syariah, merupakan salah satu rasio dalam mengukur kinerja bank dalam menghasilkan laba atau faktor rentabilitas. Net Income Margin atau Net Imbalan merupakan rasio antara pendapatan penyaluran dana setelah bagi hasil dikurangi imbalan dan bonus terhadap rata-rata total aktiva produktif. 


\subsection{BI RATE}

BI Rate menurut (Bank Indonesia, 2016) dalam (Tripuspitorini \& Setiawan, 2020) adalah suku bunga kebijakan yang mencerminkan sikap atas kebijakan moneter yang ditetapkan oleh bank Indonesia dan diumumkan kepada publik. BI Rate memiliki fungsi sebagai sinyal dari kebijakan moneter Bank Indonesia, dengan demikian dapat diartikan bahwa respon kebijakan moneter dinyatakan dalam kenaikan, penurunan, atau tidak berubahnya BI Rate tersebut. BI Rate digunakan sebagai acuan dalam operasi moneter untuk mengarahkan agar rata-rata tertimbang suku bunga SBI-1 bulan hasil lelang OPT (Operasi Pasar Terbuka) berada disekitar BI Rate. Selanjutnya suku bunga SBI-1 bulan tersebut diharapkan akan mempengaruhi suku bunga pasar uang antar Bank (PUAB), suku bunga deposito dan kredit serta suku bunga jangka waktu yang lebih panjang.

\subsection{Penelitiaan terdahulu}

Zulkhibri (2018) dalam penelitiannya yang berjudul The impact of monetary policy on Islamic bank financing: bank-level evidence from Malaysia, Adapun variabel Dependent nya Pembiayaan Bank Syariah dan variabel Independent nya Kebikakan Moeneter, metode analisis yang digunakan ada metode Regresi Data Panel, Hasil regresi ini mengatakan bahwa reaksi pembiayaan bank syariah terhadap perubahan suku bunga adalah sama seperti bank konvensional dan kuat untuk berbagai jenis ekonometrik spesifikasi. (Sulistiana, 2018) dalam penelitiannya yang berjudul "Pengaruh Non Performing Financing (NPF), Capital Adequacy Ratio (CAR), Return On Asset (ROA), Net Interest Margin (NIM) dan Biaya Operasional Pendapatan Operasional (BOPO) terhadap Financing to Deposit Ratio (FDR) pada Bank Umum Syariah di Indonesia Periode 2014-2016" yang menggunakan metode regresi linear berganda, hasil penelitian nya menunjukkan bahwa secara parsial NPF berpengaruh negatif dan signifikan terhadap FDR. CAR berpengaruh positif dan tidak signifikan terhadap FDR. ROA berpengaruh negatif dan signifikan terhadap FDR. NIM berpengaruh positif dan signifikan terhadap FDR. BOPO berpengaruh negatif dan tidak signifikan terhadap FDR. Sedangkan secara simultan NPF, CAR, ROA, NIM dan BOPO berpengaruh secara signifikan terhadap FDR

\subsection{Kerangka Pemikiran}

Kerangka pemikiran adalah campuran dari serangkaiian teorii yg ada dalaam tiinjauan teori, yang pada dasarnya adalah gambarann siistematis dari kinerja teori dalam memberikan solusi dari serangkaian masalah yang diputuskan oleh penulis. Kerangka pemikiran ini merupakan penjelasan sementara atas argumentasi peneliti dalam penelitian yang disusun secara sistematis.

Berdasarkan pemikiran penulis, gambaran ROA, CAR, NIM, dan BI Rate berpengaruh terhadap FDR dapat digambarkan secara skematis sebagai berikut

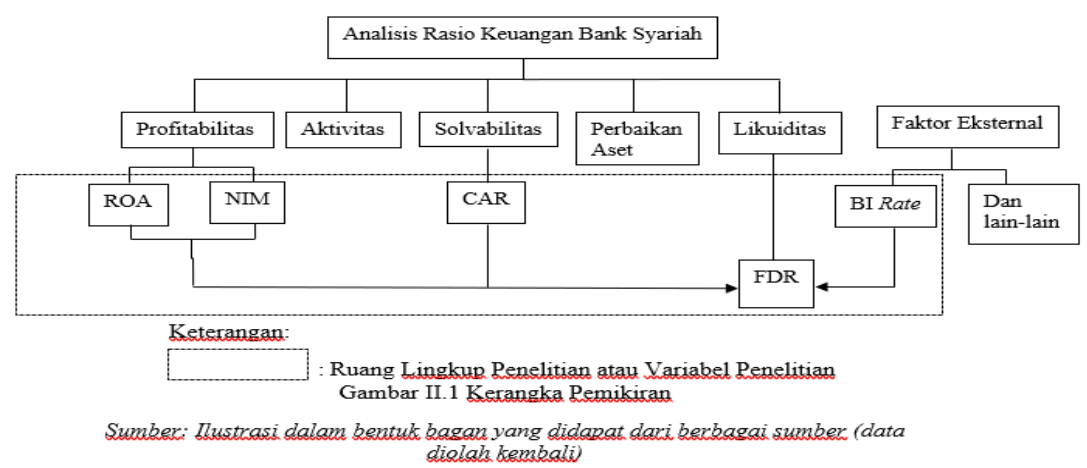

Gambar 3. Kerangka Pemikiran 


\subsection{Hipotesis Penelitian}

Berdasarkan kerangka berpikir yang sudah penulis paparkan sebelumnya, maka hipotesis dari penelitian tersebut adalah:

$\mathrm{H}_{1} \quad$ : Diduga ROA berpengaruh signifikan terhadap FDR.

$\mathrm{H}_{2} \quad$ : Diduga CAR berpengaruh signifikan terhadap FDR.

$\mathrm{H}_{3} \quad$ : Diduga NIM berpengaruh signifikan terhadap FDR.

$\mathrm{H}_{4} \quad$ : Diduga BI Rate berpengaruh signifikan terhadap FDR.

$\mathrm{H}_{5}$ : Diduga variabel ROA, CAR, NIM, dan BI Rate secara simultan berpengaruh signifikan terhadap variabel FDR.

\section{Metode Penelitian}

(Sugiyono, 2017) mengatakan bahwa metode peneliitian merupakan carailmiah untuk mendapatkandata dengan kegunaan dan tujuan tertentu. Penulis memilih memakai metode penelitian kuantitatiif dengan pendekatan deskriptiif.

Jenis data yang digunakan dalam penelitian ini menggunakan data sekunder yang merupakan data kuantitatif yaitu data berbentuk angka yang telah dipublikasikan oleh PT. Bank Muamalat Indonesia Tbk dalam bentuk laporan keuangan triwulan periode 2012-2019 yang bersifat runtun waktu atau time series. Dengan menggunakan data sekunder, data yang digunakan dapat memberikan jaminan tidak akan adanya manipulasi data yang mempengaruhi hasil penelitian karena datanya bisa diakses oleh siapapun dan dicek kebenarannya. Sumber data yang digunakan dalam penelitian ini yaitu laporan triwulan keuangan PT. Bank Muamalat Indonesia Tbk. Data PT. Bank Muamalat Indonesia Tbk diperoleh penulis dari situs (www.bankmuamalat.co.id) periode 20122019 dan dari situs Otoritas Jasa Keuangan (www.ojk.go.id). Untuk memperoleh data faktor eksternal dari bank syariah dapat diakses melalui situs Badan Pusat Statistik (www.bps.go.id).

Populasi pada penelitian ini adalah Bank Umum Syariah. Sampel pada penilitian ini adalah PT. Bank Muamalat Indonesia Tbk. Sehingga, populasi dan sampel yang digunakan oleh penulis dalam penelitian ini adalah studi kasus terhadap PT. Bank Muamalat Indonesia. Adapun alasan penelitian memilih studi kasus pada PT. Bank Muamalat Indonesia karena PT. Bank Muamalat Indonesia Tbk sebagai Bank Umum Syariah yang pertama berdiri di Indonesia memiliki rasio FDR yang dibawah ketentuan ketentuan (Bank Indonesia, 2015) dalam PBI No. 17/11/PBI/2015 yang mengatur batasan LDR atau LFR. Setelah semua data terkumpul, maka data yang terkumpul tersebut akan dianalisis dengan menggunakan teknik analisis data.

Setelah mengumpulkan data yang diperlukan dalam penelitian ini, penulis akan melaanjutkan ke tahap selanjutnya yaitu, mengolah data-data yang telah dikumpulkan dengan tujuan menjawab hipotesis yang telah penulis sampaikan pada sebelumnya. Untuk dapat mendapatkan suatu kesimpulan, penulis melakukan analisis terhadap data yang dikumpukan, penulis menggunakan model penelitian atau alat analisis regresi linier berganda dengan menggunakan Aplikasi pengolah data statistic,

Tahap pertama pengolahan data yang dilakukan oleh penulis adalah

\section{Uji asumsi klasik}

Pengujian ini dilakukan untuk menguji kualitas data sehingga data diketahui keabsahannya dan menghindari terjadinya estimasi bias, sehingga perlu dilakukan pengujian asumsii klasik.

Uji asumsi klasik yang akan digunakan pada penelitian ini, diantaranya sebagai berikut: 


\section{Uji Normalitas}

Uji normalitas digunakan untuk menguji apakah di dalam model regresi, baik variabel terikat maupun variabel bebas, keduanya mempunyai distribusi yang normal atau tidak. Model regresi yang baik adalah, model regresi yang mempunyai distribusi normal atau mendekati normal. (Ghozali, 2016)

Penelitian ini menggunakan Metode uji normalitas Kolmogorov Smirnov untuk menguji normalitas data. Apabila nilai Sig. atau Signifikansi $\mathrm{t}>0,05$ maka data tersebut menunjukan berdistribusi normal. Dan data tidak berdistribusi normal apabila nilai probabilitas $<0,05$.

\section{Uji Autokorelasi}

Uji autokorelasii memiliki tujuan untukk mengetes apakah di dalam modell regresii linier ada korelasi antara kesallahan pengganggu pada periiode -t dengan kesalahan pengganggu pada periode t- 1(sebelumnya). Penulis menggunakan uji uji statistik Durbin-Watson(DW) dalam pengujian autokorelasi penelitian ini.

\section{Uji Multikolinearitas}

Uji multikolinearitas memiliki tujuan untuk menguji apakah dalam model regresi terdapat korelasi antara variabel bebas. Indikator model regresi yang dapat diteruskan kepada tahap selanjutnya atau model regresi yang baik adalah tidak adanya korelasi di antara variabel bebas. (Ghozali, 2016).

Penelitian ini melihat nilai V ariance Inflation Factorsr(VIF) dalam menguji multikolinearitas. Jika nilai dari centered $V I F>10,00$ atau $<1$ itu berarti data tersebut mengalami multikolinearitas. Sedangkan, data yang tidak mengalami multikolinearitas terjadi apabila nilai centered $V I F<10,00$ dan $>1$.

\section{Uji Heterokedastisitas}

Uji Heterokedasitistas memiliki tujuan untuk menguji apakah pada sebuah modell regresii terjadi ketidaksamaan variian dari resiidual dalam satu pengamatan ke pengamatan lainnya. Apabila varian dari residual berbeda, disebut heteroskedastisitas. Dalam penelitian ini penulis menggunakan uji glejser, untuk menguji Heteroskedastisitas, dengan acuan bahwa :

1. Tidak terjadi heteroskedastisitas, apabila nilai signifikan $>0,05$.

2. Terjadi heteroskedastisitas, apabila nilai signifikan $<0,05$.

\section{Analisis Regresi Linear Berganda}

Penulis dalampenelitian inii menggunakan persamaan regresii linear berganda karena variiabel idependen dalam penelitian inilebih dari satu. Adapun persamaan regresi linear berganda dalam penelitian ini, dengan variabel terikat adalah FDR, dan variabel bebas yaitu ROA, CAR, NIM, ROA dan BI Rate. Sehingga model regresi linear berganda pada penelitian yang dilakukan oleh penulis adalah sebagai berikut:

$$
\mathrm{FDR}=b_{0}+b_{1} \mathrm{ROA}+b_{2} C A R+b_{3, \mathrm{NIM}}+b_{4}+b_{5} \mathrm{BI} \text { Rate }+\varepsilon
$$

Keterangan:

$$
\begin{aligned}
& \text { FDR }=\text { Financing Deposit to Ratio } \\
& \text { ROA }=\text { Return on Assets }
\end{aligned}
$$


CAR $=$ Capital Adequacy Ratio

$\mathrm{NIM}=$ Net Income Margin

BI Rate

$b_{0}=$ Konstanta

$b_{1}-b_{2}-b_{3}-b_{4}-b_{5}=$ Koefisien regresi variabel independen

$\varepsilon=$ Pengaruh faktor lain

\section{Koefisien Determinasi}

Menurut (Ghozali, 2016) Koefisien determinasi $\left(\mathrm{R}^{2}\right)$ pada utamanya mengukur seberapa jauh kemampuann modell regresii dallam menjelaskann variasii varabel bebass. Nilaii koefisieen determinaasi adalaah 0 dan 1 . Nilai $\mathrm{R}^{2}$ yg kecil berati kemampuann dari varabel-variabel bebas dlam menerngkan atau menjelaskn vriasi vriabel terikatt aamat terbatass. Nilaii yang mendekati 1 berartii variabel-variabel bebas memberikann hampir semua informasii yangg diibutuhkan untuk memprediksii variasii variabel terikatt.

\section{Pengujian hipotesis}

Uji hipotesis dalam penelitian ini dapat diukur melalui nuji $\mathrm{t}$ (parsial), dan uji $\mathrm{F}$ (simultan). Berikut deskripsi dari ketiga pengujian tersebut:

Uji t, Uji parsial ( $t$ test) dilakukan untuk mengetahui pengaruh masing-masing variabel bebas terhadap variabel terikat.

Formula Hipotesis:

Hipotesis 1

H1: $\beta_{2} \neq 0$ : Diduga ROA berpengaruh signifikan terhadap FDR.

Hipotesis 2

$\mathrm{H} 2: \beta_{3} \neq 0$ : Diduga CAR berpengaruh signifikan terhadap FDR.

Hipotesis 3

H3: $\beta_{4} \neq 0$ : Diduga NIM berpengaruh signifikan terhadap FDR.

Hipotesis 4

H4: $\beta_{5} \neq 0$ : Diduga BI Rate berpengaruh signifikan terhadap FDR.

Kriteria pengambilan keputusan pada uji t berdasarkan nilai probabilitas (signifikan) dan nilai koefisien adalah sebagai berikut:

1. Ho ditolak: jika $t_{\text {hitung }}>t_{\text {tabel }}$, atau jika $-t_{\text {hitung }}<-t_{\text {tabel }}$ atau jika $\alpha<5 \%$.

2. Ho diterima: jika $\left.t_{\text {__hitung }}\right)<t_{\text {tabel }}$, atau jika $-t_{\text {hitung }}>-t_{\text {tabel }}$, atau jika $\alpha>5 \%$.

Uji F, Uji pengaruh stimultan (F test) dilakukan untuk mengetahui apakah variabel bebas secara bersama-sama mempengaruhi variabel. Formula Hipotesis:

$\mathrm{H}_{5}: \beta_{1}, \beta_{2}, \beta_{3}, \beta_{4}, \beta_{5} \neq 0$ : diduga variabel ROA, CAR, NIM, dan BI Rate secara simultan berpengaruh signifikan terhadap variabel FDR.

Kriteria pengambilan keputusan pada uji $\mathrm{F}$ berdasarkan nilainprobabilitas (signifikan) sebagairberikut: 
Kriteria uji $\mathrm{F}$ yang digunakan adalah:

a. Ho akan ditolak: apabila $F_{\text {hitung }}>F_{\text {tabel }}$ atau apabila $\alpha<5 \%$.

Ho diterima: apabila $F_{\text {hitung }}<F_{\text {tabel }}$, atau apabila $\alpha>5 \%$.

\section{Hasil dan Pembahasan}

\section{Deskripsi Sampel Penelitian}

Tabel 1. Statistik Deskripsi Data Penelitian

\section{Descriptive Statistics}

\begin{tabular}{lr|r|r} 
& \multicolumn{1}{c}{ Mean } & \multicolumn{1}{c}{ Std. Deviation } & \multicolumn{1}{c}{$\mathrm{N}$} \\
\hline FDR & 91.0272 & 10.95675 & 32 \\
\hline ROA & .6125 & .64717 & 32 \\
\hline CAR & 13.2019 & 1.65073 & 32 \\
\hline NIM & 3.4303 & 1.26289 & 32 \\
\hline BI RATE & 6.0703 & 1.14518 & 32 \\
\hline \multicolumn{2}{l}{ Sumber: Hasil Pengolahan Data dari Aplikasi Pengolah Data Statistik }
\end{tabular}

Tabel 1 merupakan gambaran kondisi data peneliti. Dalam penelitian ini, jumlah data yang digunakan adalah 32 data untuk masing masing variabel yaitu CAR, ROA, NIM, BI Rate dan FDR.

\section{Hasil Uji Asumsi Klasik}

Hasil dari pengujian asumsi klasik yang dilakukan penulis adalah sebagai berikut:

1. Uji Normalitas

Dalam penelitian yang dilakukan penulis, penulis memilih salah satu uji statistik untuk menguji uji normalitas yaitu One-Sample Kolmogorov-Smirnov Test. Berikut hasil pengujian normalitas:

Tabel 2. Hasil Uji Normalitas One Sample Kolmogorov-Smirnov

\section{One-Sample Kolmogorov-Smirnov Test}

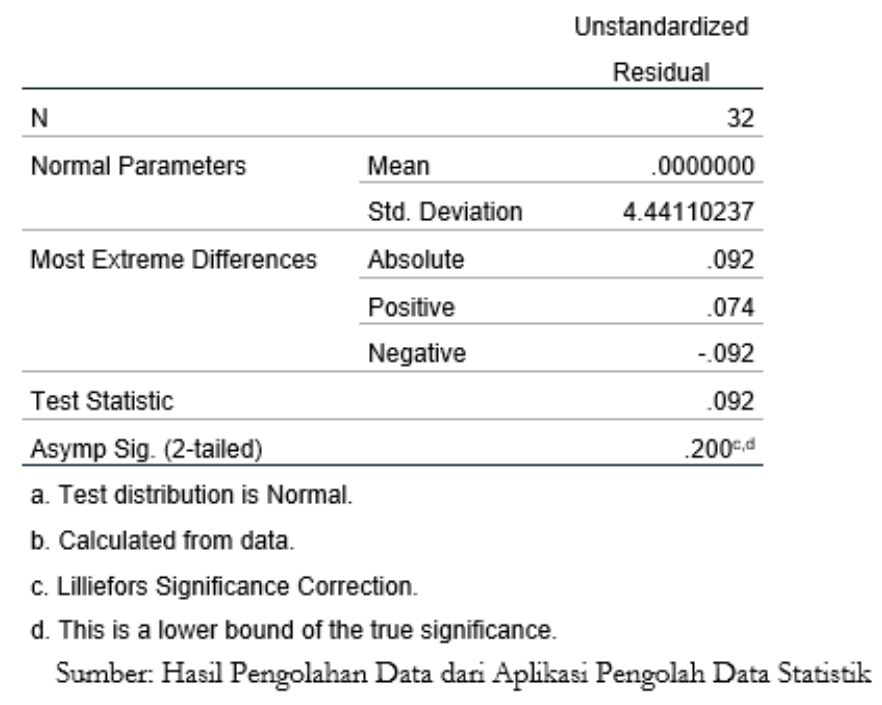

Berdasarkan Tabel 2 dapat diketahui bahwa nilai signifikasi (Asymp. Sig. 2-tailed) adalah 


\section{Hanafi Nugraha, Destian Arshad}

sebesar 0,200. Nilai signifikasi ini $>0,05$ maka residual terdistribusi normal. Dengan demikian, data variabel independen CAR, ROA, NIM, BI Rate serta variabel dependen FDR merupakan data yang berdistribusi secara normal

2. Uji Autokorelasi

Setelah dilakukan pengujian dengan metode Durbin-Watson (DW), maka didapatkan hasil yaitu sebagai berikut:

Tabel 3. Hasil Uji Autokorelasi dengan Durbin-Watson (DW-Test)

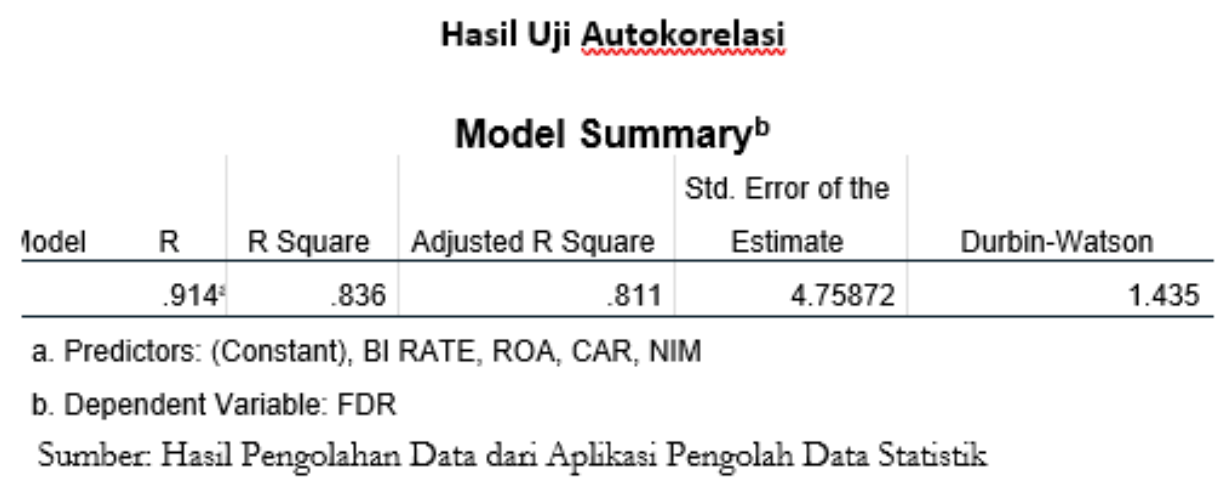

Salah satu cara untuk mendeteksi ada atau tidaknya autokorelasi adalah dengan menggunakan Uji Durbin Watson dengan berdasarkan ketentuan sebagai berikut: jika $-2<\mathrm{DW}<+2$ maka tidak ada autokorelasi. Sedangkan jika nilai angka berada pada DW $<-2$ maka terjadi autokorelasi positif, sebaliknya jika nilai angka berada pada $\mathrm{DW}>+2$ maka terjadi autokorelasi negatif, dan pada tabel diatas nilai DW 1.435 sehinnga $-2<1.435<+2$ maka tidak ada autokorelasi.

3. Uji Multikolinearitas

Untuk menguji multikolinearitas pada penelitian ini dapat dilakukan dengan melihat nilai dari Variance Inflation Factors (VIF). Berikut ini hasilnya:

Tabel 4. Hasil Uji Multikolinearitas Tolerance dan VIF

\begin{tabular}{|c|c|c|c|c|c|c|c|c|}
\hline \multicolumn{9}{|c|}{ Coefficients ${ }^{a}$} \\
\hline \multirow[b]{2}{*}{ Mods } & & \multicolumn{2}{|c|}{$\begin{array}{l}\text { Unstandardized } \\
\text { Coefficients }\end{array}$} & \multirow{2}{*}{$\begin{array}{l}\text { Standardize } \\
\text { d } \\
\text { Coefficients } \\
\text { Beta }\end{array}$} & \multirow[b]{2}{*}{$t$} & \multirow[b]{2}{*}{ Sig. } & \multicolumn{2}{|c|}{$\begin{array}{l}\text { Collinearity } \\
\text { Statistics }\end{array}$} \\
\hline & & B & Std. Error & & & & ance & VIF \\
\hline 1 & (Constant) & 65.586 & 7.248 & & 9.049 & .000 & & \\
\hline & ROA & 1.717 & 1.798 & .101 & .955 & .348 & .540 & 1.853 \\
\hline & CAR & .777 & .611 & .117 & 1.272 & .214 & .719 & 1.390 \\
\hline & NIM & 7.917 & 1.042 & .912 & 7.596 & .000 & .422 & 2.371 \\
\hline & BI RATE & -2.145 & 1.003 & -.224 & -2.138 & .042 & .553 & 1.807 \\
\hline
\end{tabular}

Tabel diatas menunjukkan bahwa VIF untuk $\mathrm{ROA}=1.853, \mathrm{CAR}=1.390, \mathrm{NIM}=2.371, \mathrm{BI}$ Rate $=1.807$ dan Tolerance untuk $\mathrm{ROA}=0.540, \mathrm{CAR}=0.719, \mathrm{NIM}=0.422$, $\mathrm{BI}$ Rate $=0.553$.

Dari data tersebut Masing-masing variabel tersebut tidak ada yang memilki nilai Tolerance kurang dari 0,10 dan tidak ada yang memiliki nilai VIF lebih dari 10. Sehingga dapat disimpulkan bahwa model regresi dapat digunakan karena tidak terjadi gejala multikolinearitas didalamnya dan bebas dari masalah multikolinieritas. 


\section{Hanafi Nugraha, Destian Arshad}

Hasil tersebut menunjukkan bahwa data penelitian layak untuk digunakan sebagai data dalam penelitian selanjutnya.

4. Uji Heterokedastisitas

Uji Glesjer adalah salah satu pengujian heterokedastisitas yang penulis pilih dalam penelitian ini. Berikut ini hasil dari uji Glejser.

Tabel 5. Hasil Uji Heteroskedastisitas dengan Uji Glejser

\begin{tabular}{|c|c|c|c|c|c|c|}
\hline \multicolumn{7}{|c|}{ Coefficients ${ }^{a}$} \\
\hline & & \multirow{2}{*}{\multicolumn{2}{|c|}{$\begin{array}{l}\text { Unstandardized } \\
\text { Coefficients }\end{array}$}} & \multirow{3}{*}{$\begin{array}{l}\text { Standardize } \\
\text { d Coefficients } \\
\text { Beta }\end{array}$} & \multirow[b]{3}{*}{$t$} & \multirow[b]{3}{*}{ Sig. } \\
\hline & & & & & & \\
\hline \multicolumn{2}{|c|}{ Model } & $\mathrm{B}$ & Std. Error & & & \\
\hline \multirow[t]{6}{*}{1} & (Constan & 3.406 & 3.696 & & .922 & .365 \\
\hline & t) & & & & & \\
\hline & ROA & -1.196 & .917 & -.322 & -1.305 & .203 \\
\hline & CAR & -.193 & .311 & -.133 & -.621 & .540 \\
\hline & NIM & .611 & .531 & .321 & 1.151 & .260 \\
\hline & BI RATE & .240 & .512 & .114 & .469 & .643 \\
\hline
\end{tabular}

a. Dependent Variable: Abs.Res

Sumber: Hasil Pengolahan Data dari Aplikasi Pengolah Data Statistik

Berdasarkan hasil Uji Heteroskedastisitas Dari tabel 5 dengan Uji Glejser diatas, dapat diketahui nilai signifikasi (Sig.) untuk $\mathrm{ROA}=0.203, \mathrm{CAR}=0.540, \mathrm{NIM}=0.260$, BI Rate $=0.643$. Karena nilai signifikasi keempat variabel diatas lebih besar dari 0,05 maka dapat disimpulkan bahwa tidak terjadi gejala heteroskedastisitas pada model regresi.

\section{Analisis Regresi Linear Berganda}

Analisis regresi linier berganda digunakan untuk mengetahui pola hubungan antara variabel independen yaitu ROA (X1), CAR (X2), NIM (X3), dan BI Rate (X4) dengan variabel dependen-nya yaitu FDR $(\mathrm{Y})$. Analisis regresi berganda dapat disajikan pada tabel berikut.:

Tabel 6. Hasil Uji Analisis Regresi Berganda

\begin{tabular}{|c|c|c|c|c|c|c|}
\hline & & & oefficient & & & \\
\hline & & Unstandardize & Coefficients & $\begin{array}{l}\text { Standardized } \\
\text { Coefficients }\end{array}$ & & \\
\hline Model & & $\mathrm{B}$ & Std. Error & Beta & $\mathrm{t}$ & Sig. \\
\hline 1 & (Constant) & 65.586 & 7.248 & & 9.049 & .000 \\
\hline & $\mathrm{ROA}$ & 1.717 & 1.798 & .101 & .955 & .348 \\
\hline & CAR & .777 & .611 & .117 & 1.272 & .214 \\
\hline & NIM & 7.917 & 1.042 & .912 & 7.596 & .000 \\
\hline & BI RATE & -2.145 & 1.003 & -.224 & -2.138 & .042 \\
\hline
\end{tabular}

a. Dependent Variable: FDR

Dari tabel 6 hasil uji regresi linier berganda diatas, maka dapat digambarkan persamaan regresi sebagai berikut :

$$
\begin{aligned}
& \mathrm{Y}=a+\mathrm{b}_{1} \mathrm{X}_{1}+\mathrm{b}_{2} \mathrm{X}_{2}+\mathrm{b}_{3} \mathrm{X}_{3} \\
& \mathrm{Y}=65,586+(0,955) \mathrm{X}_{1}+1,272 \mathrm{X}_{2}+(7,596) \mathrm{X}_{3}+(-2,138) \mathrm{X}_{4} \\
& \mathrm{Y}=65,586+0,955 \mathrm{X}_{1}+1,272 \mathrm{X}_{2}+7,596 \mathrm{X}_{3}-2,138 \mathrm{X}_{4}
\end{aligned}
$$




\section{Koefisien Determinasi $\left(\mathbf{R}^{2}\right)$}

Berikut ini merupakan hasil pengujian koefisien determinasi:

Tabel 7. Hasil Uji Koefisien Determinasi

\begin{tabular}{|c|c|c|c|c|c|}
\hline \multicolumn{6}{|c|}{ Model Summary ${ }^{b}$} \\
\hline Model & $\mathrm{R}$ & R Square & $\begin{array}{l}\text { Adjusted R } \\
\text { Square }\end{array}$ & $\begin{array}{l}\text { Std. Error of the } \\
\text { Estimate }\end{array}$ & Durbin-Watson \\
\hline 1 & $.914^{\mathrm{a}}$ & .836 & .811 & 4.75872 & 1.435 \\
\hline
\end{tabular}

Angka adjusted $\mathrm{R}$ Square adalah 0,811 atau 81,1\%, artinya 0,811 variabel terikat FDR diterangkan oleh variabel independen yaitu ROA, CAR, NIM, dan BI Rate dan sebagiannya diterangkan oleh variabel lain di luar variabel-variabel yang dianalisis oleh penulis. Jadi sebagian besar variabel dependen dijelaskan oleh variabel-variabel independen yang tidak digunakan oleh penulis dalam model regresi yang dianalisis.

\section{Uji Parsial (Uji t)}

Tabel 8. Hasil Pengujian Hipotesis dengan Uji t

\begin{tabular}{|c|c|c|c|c|c|c|}
\hline \multicolumn{7}{|c|}{ Coefficientsa } \\
\hline \multirow[b]{2}{*}{ Model } & & \multicolumn{2}{|c|}{ Unstandardized Coefficients } & \multirow{2}{*}{$\begin{array}{c}\text { Standardized } \\
\text { Coefficients } \\
\text { Beta }\end{array}$} & \multirow[b]{2}{*}{$\mathrm{t}$} & \multirow[b]{2}{*}{ Sig. } \\
\hline & & $\mathrm{B}$ & Std. Error & & & \\
\hline \multirow[t]{5}{*}{1} & (Constant) & 65.586 & 7.248 & & 9.049 & .000 \\
\hline & $\mathrm{ROA}$ & 1.717 & 1.798 & .101 & .955 & .348 \\
\hline & CAR & .777 & .611 & .117 & 1.272 & .214 \\
\hline & NIM & 7.917 & 1.042 & .912 & 7.596 & .000 \\
\hline & BI RATE & -2.145 & 1.003 & -.224 & -2.138 & .042 \\
\hline
\end{tabular}

a. Dependent Variable: FDR

Sumber: Hasil Pengolahan Data dari Aplikasi Pengolah Data Statistik

\section{Dari tabel diatas Coefficient dijelaskan hasil uji sebagai berikut:}

\section{Variabel Return on Assets (X1)}

Dari tabel 9, nilai Sig. untuk variabel Return on Assets nilainya 0,348, lalu bila dibandingkan dengan taraf Sig. $(\alpha=0,05)$ hasilnya 0,348>0,05. Dapat diambil kesimpulan bahwa H1 tidak diterima yang berarti menjelaskan bahwa Return on Assets tidak berpengaruh secara signifikan terhadap FDR PT. Bank Muamalat Indonesia Tbk. Jadi H1 ditolak.

Jika dilakukan dengan melihat ttabel dan thitung maka ttabel: 2,05183 (didapatkan dengan cara mencari nilai $\mathrm{df}=\mathrm{n}-\mathrm{k}-1=3-4-1=27$, dan membagi 2 nilai $\alpha 5 \%$ yaitu $\left.\frac{5 \%}{2}=0,025\right)$ dan thitung $=(0.955)$. thitung $<$ ttabel $=0.955<2,05183$ maka hipotesis tidak teruji atau hipotesis pertama 


\section{Hanafi Nugraha, Destian Arshad}

ditolak yaitu Return on Assets tidak berpengaruh secara signifikan dan positif terhadap FDR PT. Bank Muamalat Indonesia Tbk Tahun 2012-2019.

\section{Variabel Capital Adequacy Ratio (X2)}

Dari 9 dapat dilihat nilai Sig. untuk variabel Capital Adequacy Ratio nilainya 0,214 lalu apabila dibandingkan dengan taraf Sig. $(\alpha=0,05)$ hasilnya $0,214>0,05$.Sehingga dapat diambil kesimpulan bahwa $\mathrm{H} 2$ tidak diterima, hal ini menyimpulkan bahwa Capital Adequacy Ratio tidak berpengaruh secara signifikan terhadap FDR PT. Bank Muamalat Indonesia Tbk. Jadi hipotesis 2 tidak diterima

Apabila dengan melihat ttabel dan thitung, maka ttabel: 2,05183 (didapatkan dengan cara mencari nilai $\mathrm{df}=\mathrm{n}-\mathrm{k}-1=32-4-1=27$, dan membagi 2 nilai $\alpha 5 \%$ yaitu $\left.\frac{5 \%}{2}=0,025\right)$ dan thitung $=(1,272)$. thitung $<$ ttabel $=1,272<2,05183$ maka hipotesis tidak teruji atau hipotesis kedua ditolak yaitu Capital Adequacy Ratio tidak berpengaruh secara positif dan signifikan terhadap FDR PT. Bank Muamalat Indonesia Tbk Tahun 2012-2019.

3. Variabel Net Income Margin (X3)

Dari tabel 9 dapat dilihat untuk nilai variabel Net Income Margin adalah 0,000 apabila dibandingkan dengan taraf Sig. $(\alpha=0,05)$ hasilnya sebagai berikut $0,000<0,05$, sehingga dapat diambil kesimpulan bahwa $\mathrm{H} 3$ tidak ditolak atau diterima yang artinya bahwa Net Income Margin berpengaruh signifikan terhadap FDR Bank Muamalat Indonesia. Jadi hipotesis ketiga teruji dan diterima

Jika dilakukan dengan melihat ttabel dan thitung maka ttabel: 2,05183 (didapatkan dengan cara mencari nilai $\mathrm{df}=\mathrm{n}-1=32-4-1=27$, dan membagi dua nilai $\alpha 5 \%$ yaitu $\left.\frac{5 \%}{2}=0,025\right)$ dan thitung $=(7,596)$. thitung $>$ ttabel $=7,596>2,05183$ maka hipotesis teruji atau hipotesis ketiga diterima yaitu Net Income Margin berpengaruh secara positif dan signifikan terhadap FDR Bank Muamalat Indonesia Tahun 2012-2019.

\section{Variabel BI Rate (X4)}

Dari tabel 9, dapat dilihat nilai Sig, untuk variabel BI Rate nilainya 0,042 apabila dibandingkan dengan taraf signifikansi $(\alpha=0,05)$ maka hasilnya $0,042<0,05$, sehingga dapat diambil kesimpulan bahwa H5 diterima yang menjelaskan bahwa BI Rate berpengaruh signifikan terhadap FDR PT. Bank Muamalat Indonesia Tbk. Jadi hipotesis 4 teruji dan diterima.

Jika dilakukan dengan melihat ttabel dan thitung maka t tabel $=2,05183$ (didapatkan dengan cara mencari nilai $\mathrm{df}=\mathrm{n}-4-1=32-4-1=27$, dan membagi 2 nilai $\alpha 5 \%$ yaitu $\left.\frac{5 \%}{2}=0,025\right)$ dan thitung $=(-2,138)$. Thitung $>$ ttabel $=-2,138>-2,05183$ maka hipotesis teruji atau hipotesis keempat diterima yaitu BI Rate secara negatif terhadap FDR Bank Muamalat Indonesia Tahun 2012-2019. 


\section{Hanafi Nugraha, Destian Arshad}

\section{Uji Simultan (Uji F)}

Tabe1 9. Hasil Pengujian Hipotesis dengan Uji F

\begin{tabular}{|c|c|c|c|c|c|c|}
\hline \multicolumn{7}{|c|}{ ANOVAa $^{a}$} \\
\hline Model & & Sum of Squares & df & Mean Square & $\mathrm{F}$ & Sig. \\
\hline \multirow[t]{3}{*}{1} & Regression & 3110.139 & 4 & 777.535 & 34.335 & $.000^{b}$ \\
\hline & Residual & 611.425 & 27 & 22.645 & & \\
\hline & Total & 3721.564 & 31 & & & \\
\hline \multicolumn{7}{|c|}{ a. Dependent Variable: FDR } \\
\hline \multicolumn{7}{|c|}{ b. Predictors: (Constant), BI RATE, ROA, CAR, NIM } \\
\hline
\end{tabular}

Jika kita melihat dari Sig. dapat tergambar bahwa dari hasil pengujian Regresi di atas dapat dilihat dari Uji F dengan nilai Sig. level pada tabel output nilainya 0.000 . Hal ini menunjukan bahwa Nilai Sig. $<0,05$. Hal ini menjawab hipotesis bahwa Ho ditolak sedangkan H5 diterima artinya ada pengaruh antara ROA, CAR, NIM, dan BI Rate terhadap FDR PT. Bank Muamalat Indonesia Tbk secara bersama-sama atau simultan.

Jika kita melihat dari nilai $\mathrm{F}$ tabel dan $\mathrm{F}$ hitung dimana $\mathrm{F}$ tabel=2,73 (didapatkan dengan cara mencari df 1 dan df 2 . df $=\mathrm{k}=4, \mathrm{k}=$ jumlah variabel bebas, $\mathrm{V} 2=\mathrm{n}-\mathrm{k}-1=32-4-1=27)$. Untuk Fhitung(30,0099) $>$ Ftabel $(2,73)$ maka H5 terbukti, yaitu ada Pengaruh signifikan antara ROA, CAR, NIM, dan BI Rate terhadap FDR Bank Muamalat Indonesia secara simultan (bersama-sama).

\section{Pengaruh ROA terhadap FDR}

Berdasarkan hasil penelitian Return on Assets (ROA) berpengaruh positif dan tidak signifikan terhadap FDR. Hal ini mengindikasikan bahwa apabila rasio ROA meningkat maka nilai rasio FDR akan meningkat juga namun tidak signifikan.

Hasil tidak signifikan ini diduga disebakan karena perubahan ROA tidak berpengaruh besar kepada perubahan jumlah pembiayan yang disalurkan terhadap DPK karena dilihat dari rumusnya pun rasio ROA yang dihitung dari laba sebelum pajak terhadap rata-rata total aktiva bahwa nilai rasio ROA didapatkan dari rata-rata total aset yang dimana aset dari suatu bank ada banyak seperti Investasi pada efek/surat berharga, kas, giro pada bank lain, Penempatan pada bank lain, berbagai piutang, pembiayaan mudharabah, pembiayaan musyarakah dan lain lain. Sehingga hal tersebut yang menyebabkan ROA berpengaruh positif tidak signifkan terhadap FDR. Hasil penelitian ini mendukung penelitian yang dilakukan (Ramadhani \& Indriani, 2016)mendapatkan hasil bahwa Variabel ROA berpengaruh positif tidak signifikan terhadap LDR.

\section{Pengaruh CAR terhadap FDR}

Berdasarkan hasil penelitian Capital Adequecy Ratio (CAR) berpengaruh positif dan tidak signifikan terhadap FDR. Hal ini mengindikasikan bahwa semakin tinggi rasio CAR dapat menyebabkan peningkatan FDR.

Hasil tidak signifikan ini diduga disebabkan rasio CAR secara konsep rasio CAR secara konsep menurut (Otoritas Jasa Keuangan, 2014) merupakan perbandingan antara jumlah modal dibagi dengan ATMR (Aktiva Tertimbang Menurut Risiko). Salah satu aktiva bank yang berisiko adalah pembiayaan, sehingga meningkatnya nilai CAR bisa diakibatkan ATMR bank yang semakin kecil atau jumlah pembiayan yang disalurkan semakin kecil. 


\section{Hanafi Nugraha, Destian Arshad}

Selain itu, tidak signifikan juga bisa disebabkan karena kurangnya pemanfaatan dana dengan baik, sehingga peningkatan modal yang tidak dibarengi dengan peningkatan penyaluran pembiayaan yang efektif dan efisien yang akan meningkatkan keuntungan secara signifikan dari pemanfaatan modal yang dimiliki. Sehingga pengaruh positif CAR terhadap FDR pun tidak signifikan.

Hasil penelitian ini juga sesuai dengan penelitian yang dilakukan (Sulistiana, 2018) dan (Ramadhani \& Indriani, 2016) mendapatkan hasil bahwa Variabel CAR berpengaruh positif dan tidak signifikan terhadap FDR atau LDR

\section{Pengaruh NIM terhadap FDR}

Hasil penelitian menunjukkan bahwa NIM berpengaruh positif dan signifikan dengan FDR. Hal ini mengindikasikan bahwa NIM berbanding lurus dengan FDR. Hal ini berarti peningkatan NIM akan menyebabkan peningkatan FDR dan sebaliknya penurunan NIM akan menyebabkan penurunan FDR.

Hal ini selaras dengan pendapat (Sulistiana, 2018) dalam penelitiannya yang menyebutkan bahwa hubungan NIM dengan FDR mempunyai Pengaruh yang positif dan signifikan.

\section{Pengaruh BI Rate terhadap FDR}

Berdasarkan hasil penelitian BI Rate berpengaruh negatif dan signifikan terhadap FDR. Hal ini mengindikasikan bahwa semakin tinggi nilai BI Rate yang ditentukan oleh bank Indonesia, maka jumlah pembiayaan yang disalurkan berkurang karena jumlah dana masyarakat berkurang.

Hasil penelitian ini juga mendukung penelitian yang dilakukan oleh (Zulkhibri, 2018) yang mengatakan bahwa reaksi pembiayaan bank syariah terhadap perubahan suku bunga adalah sama seperti bank konvensional dan kuat untuk berbagai jenis ekonometrik spesifikasi.

\section{Pengaruh ROA, CAR, NIM, dan BI Rate terhadap FDR}

Berdasarkan hasil penelitian ROA, CAR, NIM, dan BI Rate berpengaruh signifikan terhadap FDR Bank Muamalat Indonesia secara simultan (bersama-sama). Hal ini ditunjukkan dengan nilai signifikansi $F=0,000$ (lebih kecil dari $\alpha=0,05$ ) pada pengujian uji simultan (uji $F$ ) dan $F$ hitung $(30,0099)>$ F tabel $(2,73)$. Selain dilihat dari hasil uji statistik, pengaruh ROA, CAR, NIM, dan BI Rate berpengaruh terhada FDR bisa dilihat dalam perubahan keempat varibel selama periode penelitian yang bersama-sama lebih banyak mengalami penurunan sehingga nilai FDR pun mengalami banyak penurunan.

\section{Penutup}

Berdasarkan pembahasan yang telah disampaikan, maka kesimpulan yang dapat diambil dalam penelitiaan ini adalah sebagai berikut :

1. Retum on Assets (ROA) secara parsial tidak berpengaruh signifikan terhadap Financing to Deposit Ratio (FDR), hal ini menunjukan bahwa meningkatnya kemampuan bank syariah dalam mengelola aset tidak berpengaruh signfikan terhadap peningkatan penyaluran dana untuk pembiayaan terhadap dana pihak ketiga. Hasil ini tidak sesuai dengan teori dan hipotesis, hal ini diduga disebakan karena aset bank syariah ada banyak seperti investasi pada efek/surat berharga, kas, giro pada bank lain, penempatan pada bank lain jadi tidak hanya pembiayaan.

2. Capital Adequacy Ratio (CAR) secara parsial tidak berpengaruh signifikan terhadap Financing to Deposit Ratio (FDR), hal ini menggambarkan bahwa meningkatnya modal yang disediakan bank 


\section{Hanafi Nugraha, Destian Arshad}

syariah tidak berpengaruh signfikan terhadap peningkatan penyaluran dana untuk pembiayaan terhadap dana pihak ketiga. Hasil ini tidak sesuai dengan teori dan hipotesis, hal ini diduga karena kurangnya pemanfaatan modal dengan baik, sehingga peningkatan modal yang tidak dibarengi dengan peningkatan penyaluran pembiayaan yang efektif dan efisien.

3. Net Income Margin (NIM) secara parsial berpengaruh signifikan terhadap Financing to Deposit Ratio (FDR), hal ini menunjukan bahwa meningkatnya kemampuan bank syariah dalam mengelola aktiva produktif berpengaruh signfikan terhadap peningkatan penyaluran dana untuk pembiayaan terhadap dana pihak ketiga. Hasil ini sesuai dengan teori dan hipotesis.

4. BI Rate secara parsial berpengaruh signifikan terhadap Financing to Deposit Ratio (FDR), hal ini menunjukan bahwa meningkatnya kemampuan bank syariah dalam mengelola aktiva produktif berpengaruh signfikan terhadap peningkatan penyaluran dana untuk pembiayaan terhadap dana pihak ketiga. Hasil ini sesuai dengan teori dan hipotesis.

5. Return on Assets (ROA), Net Income Margin (NIM), Capital Adequacy Ratio (CAR), dan BI Rate berpengaruh signifikan secara bersama-sama (simultan) terhadap Financing to Deposit Ratio (FDR), Hasil ini sesuai dengan teori dan hipotesis.

Demi tercapainya manfaat yang optimal, dan pengembangan dari hasil penelitian yang dilakukan penulis, penulis memberikan saran untuk pihak-pihak yang berkepentingan di masa yang akan datang sebagai berikut :

1. Perbankan syariah

Penelitian ini diharapkan dapat dijadikan sebagai bahan pertimbangan manajemen Bank Umum Syariah, khususnya Bank Muamalat Indonesia dalam hal pengambilan keputusan yang dapat mempengaruhi kinerja keuangan perbankan sehingga bank syariah dapat mengoptimalkan Pengeloaan Pembiayaan, Menyediakan Modal Lebih banyak, Memanfaatkan Kebijakan BI, Adaptif dan Inovatif terhadap perkembangan teknologi.

\section{Pemerintah}

Mengesahkan regulasi yang dapat mengoptimalkan dan mendukung perbankan syariah dan mengatur tata kelola tentang ekonomi syariah.

\section{Akademisi}

Penelitian ini dapat dijadikan sebagai salah satu referensi dan informasi tambahan dalam pengembangan ilmu keuangan dan perbankan syariah peneliti selanjutnya dengan topik yang serupa mengenai analisis Financing Deposit Ratio (FDR).

a. Penelitian selanjutnya disarankan dapat memperpanjag periode \& menambah Variabel, Memperluas Objek Pengamatan dan menggunakan penelitian ini sebagai bahan perbadnigan dan referensi untuk penelitian selanjutnya.

\section{Daftar Pustaka}

Astuti, F. (2016). Pengaruh Efisiensi Usaha, Risiko Keuangan dan Kepercayaan Masyarakat terhadap Kemampuan Penyaluran Pembiayaan pada Bank Umum Syariah di indonesia Tahun 2011-2014. Jurnal Ekonomi \& Kenangan Islam, 2(2), 10-20. https://doi.org/10.20885/jeki.vol2.iss2.art2

Badan Pusat Statistik. (2020). BI Rate. https://www.bps.go.id/dynamictable/2015/12/22 00:00:00/1061/bi-rate-2005-2018.html 


\section{Hanafi Nugraha, Destian Arshad}

Bank Indonesia. (2015). Peraturan Bank Indonesia No. 17/11/PBI/2015 tanggal 25 Juni 2015 tentang Perubahan Atas Peraturan Bank Indonesia Nomor 15/15/PBI/ 2013 tentang Giro Wajib Minimum Bank Umum Dalam Rupiah Dan valuta Asing Bagi Bank Umum Konvensional. https://www.bi.go.id/id/peraturan/ssk/Pages/pbi_171115.aspx

Bank Indonesia. (2016). INFORMASI DASAR DEFINISI DATA - Bank Indonesia. https://www.bi.go.id/id/statistik/metadata/seki/Documents/8_Suku_Bunga_Indo_DPM SEKI_2016 (Indonesia) new.pdf

Fahmi, I. (2015). Manajemen Perbankan Konvensional \& Syariah. Mitra Wacana Media.

Fathonah, A. S., \& Hermawan, D. (2020). Estimasi Pengaruh Faktor Internal Bank Dan Dengan Mediasi Rasio Pembiayaan Bermasalah Di Pt. Bank Muamalat Indonesia. Manajemen Perbankan Syariah, 3, No. 2, 93-108.

Ghozali, I. (2016). Aplikasi Analisis Multivariete Dengan Program IBM SPSS 23 (Edisi 8). Cetakan ke VIII. Badan Penerbit Universitas Diponegoro.

Otoritas Jasa Keuangan. (2014). Surat Edaran Otoritas Jasa Keuangan (SEOJK) Nomor 10/SEOJK.03/2014 tentang Penilaian Tingkat Kesehatan Bank Umum Syariah dan Unit Usaba Syariah. https://www.ojk.go.id/id/regulasi/otoritas-jasa-keuangan/surat-edaran-ojk-dandewan-komisioner/Documents/seojk102014_1403094627.pdf

PT. Bank Muamalat Indonesia Tbk. (2020). Laporan Tahunan dan Laporan Triwulan. https://www.bankmuamalat.co.id/hubungan-investor/laporan-triwulan

Ramadhani, A. N., \& Indriani, A. (2016). Analisis Pengaruh Size, Capital Adequacy Ratio ( Car), Return on Assets ( Roa), Non Performing Loan ( $\mathrm{Npl}$ ), Dan Inflasi Terhadap Loan To Deposit Ratio ( Ldr ). Diponegoro Journal of management, 5(2), 1-15. http://ejournals1.undip.ac.id/index.php/management

Sa'idah, S. H., \& Mauluddi, H. A. (2018). Bank Muamalat Indonesia Profitability Analysis : Study Of The Effects Of Capital, Asset Quality, Earnings And Liquidity Analisis Profitabilitas Bank Muamalat Indonesia: Studi Pengaruh Permodalan, Kualitas Asset, Earnings Dan. 14(1), 69-81.

Setiawan, S. (2018). Determinan Penentu Pertumbuhan Dana Pihak Ketiga Perbankan Syariah di Indonesia. Jurnal Maps (Manajemen Perbankan Syariab), 1(2), 1-9.

Sugiyono. (2017). Metode Penelitian Kuantitatif, Kualitatif, dan R\&D. Alfabeta.

Sulistiana, E. (2018). SKRIPSI Oleb Erma Sulistiana NIM. 1741143110.

Tripuspitorini, \& Setiawan. (2020). Pengaruh Variabel Makroekonomi Terhadap Dana Pihak Ketiga Bank Umum Syariah Di Indonesia. Jumal Muara Imu Ekonomi Dan Bisnis, 4(1), 164. https://doi.org/10.24912/jmieb.v4i1.7299

Zulkhibri, M. (2018). The impact of monetary policy on Islamic bank financing: bank-level evidence from Malaysia. Journal of Economics, Finance and Administrative Science, 23(46), 306-322. https://doi.org/10.1108/JEFAS-01-2018-0011 